\title{
Efficacia Dell'impiego Di Un Symbiotic Dietary Supplement (SDS) on Body Weight in Perimenopausal Women
}

\author{
Marco Gambacciani* \\ Department of Obstetrics and Gynecology, University of Pisa, Italy \\ Submission: February 28, 2018; Published: March 29, 2018 \\ *Corresponding author: Marco Gambacciani, Department of Obstetrics and Gynecology, University of Pisa, Italy
}

Keywords: Body weight; Menopause; Symbiotic dietary supplement

\section{Introduction}

Obesity is a major health concern in the western world, with more than one-third of adults estimated to be obese [1]. A trend to a progressive increase in body weight (BW) is often observed throughout the climacteric period associated not only with chronological age but also several other factors, including hormonal changes, menopause-related lifestyle changes, and type of menopause [1-5]. Different lines of evidence suggest that menopause per se is related to an increase in BW [6-12]. The issue of body weight has a great importance regarding the quality of life postmenopausal and perimenopausal women, and it has considerable impact on the health of PMW, including hypertension, cardiovascular disease, stroke, diabetes, hip fractures, cancer, premature death and disability when compared to PMW with a normal weight and normal body mass index (BMI) [6-12].

Evidence supports that the human gut microbiome is related to an increased BW obesity $[13,14]$. In this prospective study we evaluated the effects of a symbiotic dietary supplement (SDS) administration on body weight in perimenopausal women.

\section{Materials and Methods}

From women attending to the Menopause Clinic we selected untreated, normal healthy perimenopausal oligomenorrhoic women. Oligomenorrhea was defined as episodes of menstrual bleeding occurring at intervals of more than 35 and less than 90 days. All subjects had no history of diabetes, eating disorders, liver disease or other disorders known to influence calcium metabolism and none had received a glucocorticoid treatment. Women that were smoking 15 or more cigarettes a week exercised more than $6 \mathrm{~h}$ /week were excluded. Inclusion criteria included normal thyroid, adrenal, and renal function, as assessed by clinical, biochemical and hormonal evaluations. None had been treated with hormones in the 6 months before observation Fifteen consecutive women received SDS ( 1 sachet a day) for 3 months and 15 untreated women were used as controls. Body weight was measured and the Body Mass Index (BMI) was calculated as weight (kilograms) divided by the square of the height (meters). All the results are reported as the Mean \pm SE [15].

\section{Statistical Analysis}

Mean values were compared by paired and unpaired Student's t test.

\section{Results}

Table 1 reports the characteristics of the perimenopausal women. Five patients in the Control untreated group and 4 patients in the SDS group were lost at the follow up. There were no differences in age, height and cycle length in the two groups before entering the study. In control group, an increase in BW (not statistically significant; p value 0.051 ) from $62.6 \pm 4.1$ to $63.4 \pm 4.3 \mathrm{Kg}$ was observed after 3 months). Similarly BMI in control group did not show any difference from basal values of $25.2 \pm 0.9$ to $25.3 \pm 0.1$ after 3 months. Conversely, a statistically significant decrease in BW was recorded in SDS treated women from the basal values of $69,8 \pm 4.3 \mathrm{Kg}$, to $68.6 \pm 3.5 \mathrm{Kg}$ after 3 months, with a two tailed $\mathrm{P}$ values of 0.05 ; the difference equals 1.17 with a 95\% confidence interval from 0.001 to 2.344 . Similarly, BMI from basal values of $25.0 \pm 1.7$, in SDS treated women showed a significant $(\mathrm{p}<0.05)$ decrease to $24.5 \pm 1.5$; the difference equals 0.4182 , with a $95 \%$ confidence interval from 0.0032 to 0.8332 .

\section{Discussion}

The results of this longitudinal, open study suggest that the administration of the SDS may counteract the increase in BW 
observed in the perimenopausal period. SDS may help to maintain or even lead to a small but statistically significant decrease in BW in perimenopausal women. Present results suggest that the climacteric, perimenopausal changes may interfere with gut microbioma, since the SDS may help women in maintaining and even reduce the BW. Further studies are needed to characterize the effects of SDS on gut microbioma. In addition, present results confirm the tendency to an increase in BW in perimenopausal period, albeit the difference between basal and the three months values did not reach statistical significance. The short period of observation and the small group of women included in our analysis may explain the borderline significant difference in BW from baseline values.

Present study has certain limitations, due its observational nature, and conducted in a small group of women. In addition in our pilot study we did not evaluated the body fat distribution, an independent risk factor for cardiovascular disease in postmenopausal women. This aspect as well as other variables such as lipid profile and blood pressure and glucose tolerance warrant further studies. Longitudinal, randomized and properly sized studies are needed in order to further evaluate the changes in gut microbioma during perimenopausal transition and the possible effects of SDS on BW.

\section{References}

1. Ogden CL, Carroll MD, Curtin LR, McDowell MA, Tabak CJ, et al. (2006) Prevalence of overweight and obesity in the United States, 1999-2004. JAMA 295(13): 1549-1555.

2. Rosano GM, Fini M (2002) Postmenopausal women and cardiovascular risk: impact of hormone replacement therapy. Cardiol Rev 10(1): 5160.

3. Al-Safi ZA, Polotsky AJ (2015) Obesity and menopause, Best practice \& research. Clin Obstet Gynaecol 29(4): 548-553.

4. Gibson CJ, Thurston RC, El Khoudary SR, Sutton-Tyrrell K, Matthews KA (2013) Body mass index following natural menopause and hysterectomy with and without bilateral oophorectomy. Int J Obes (Lond.) 37(6): 809-813.

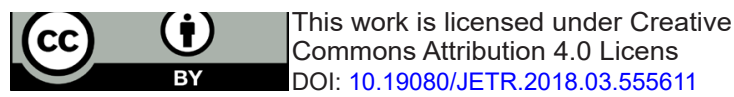

5. Evans DJ, Hoffman RG, Kalkoff RK, Kissebah AH (1983) Relationship of androgenic activity to body topography, fat cell morphology and metabolic aberrations in premenopausal women. J Clin Endocrinol Metab 57(2): 304-310.

6. Burger HG, Dudley EC, Hopper JL, Shelley JM, Green A, et al. (1995) The endocrinology of the menopausal transition: a cross-sectional study of a population-based sample. J Clin Endocrinol Metab 80(12): 35373545.

7. Dallongeville J, Marecaux N, Isorex D, Zylberg G, Fruchart JC, et al. (1995) Multiple coronary heart disease risk factors are associated with menopause and influenced by substitutive hormonal therapy in a cohort of French women. Atherosclerosis 118(1): 123-133.

8. Gambacciani M, Ciaponi M, Cappagli B, Piaggesi L, De Simone L, et al. (1997) Body weight, body fat distribution, and hormonal replacement therapy in early postmenopausal women. J Clin Endocr Metab 82(2): 414-417.

9. Heiss CJ, Sanborn CF, Nichols DL, Bonnick SL, Alford BB (1995) Association of body fat distribution, circulating sex hormones, and bone density in postmenopausal women. J Clin Endocr Metab 80(5): 1591-1596.

10. Gambacciani M, Ciaponi M, Cappagli B, De Simone L, Orlandi R, et al. (2001) Prospective evaluation of body weight and body fat distribution in early postmenopausal women with and without hormonal replacement therapy. Maturitas 39(2): 125-132.

11. Gambacciani M, Ciaponi M, Cappagli B, Benussi C, De Simone L, et al. (1999) Climacteric modifications in body weight and fat tissue distribution. Climacteric 2(1): 37-44.

12. The Writing Group for the PEPI Trial (1995) Effects of estrogen and estrogen/progestin regimens on heart disease risk factors in postmenopausal women. The Postmenopausal Estrogen/progestin Interventions (PEPI) trial. The Writing Group for the PEPI Trial. JAMA 273(3): 199-208.

13. Tennyson CA, Friedman G (2008) Microecology, obesity, and probiotics. Curr Opin Endocrinol Diabetes Obes 15(5): 422-427.

14. Hullar MA, Lampe JW (2012) The gut microbiome and obesity. Nestle Nutr Workshop Ser 73: 67-79.

15. Ley CJ, Lees B, Stevenson JC (1992) Sex- and menopause-associated changes in body-fat distribution. Am J Clin Nutr 55(5): 950-954.

\section{Your next submission with Juniper Publishers will reach you the below assets}

- Quality Editorial service

- Swift Peer Review

- Reprints availability

- E-prints Service

- Manuscript Podcast for convenient understanding

- Global attainment for your research

- Manuscript accessibility in different formats

( Pdf, E-pub, Full Text, Audio)

- Unceasing customer service

Track the below URL for one-step submission https://juniperpublishers.com/online-submission.php 